\title{
Contribution to Understanding of Ore Fluids in the Zletovo Mine Based on Fluid Inclusion Data
}

\author{
Raziskave Rudnih Fluidov v Rudniku Zletovo s Pomočjo \\ Tekočinskih Vključkov
}

\author{
Goran Tasev' ${ }^{1}$, Todor Serafimovski' ${ }^{1}$, Matej Dolenec ${ }^{2}$, Nastja Rogan Šmuc ${ }^{2, *}$ \\ ${ }^{1}$ Goce Delcev University, Faculty of Natural and Technical Sciences, Stip, R. Macedonia \\ ${ }^{2}$ University of Ljubljana, Faculty of Natural Sciences and Engineering, Department of Geology, Ljubljana, Slovenia \\ *nastja.rogan@guest.arnes.si
}

\begin{abstract}
The Zletovo is lead-zinc (Pb-Zn) deposit, adjacent to the Plavica volcanic centre (R. Macedonia) with high-sulphidation and porphyry mineralisation. The analysis of fluid inclusions showed homogenisation temperatures in the range $335-145^{\circ} \mathrm{C}$, which reflects phases of pulsation of hydrothermal solutions and defined into four groups from the lowest to the highest temperatures. The frequency of the homogenisation temperatures ranged from 265 to $125^{\circ} \mathrm{C}$ and with the most dominant from 245 to $225^{\circ} \mathrm{C}$, from 225 to $205^{\circ} \mathrm{C}$ and from 145 to $125^{\circ} \mathrm{C}$. Also, it was confirmed that hydrothermal ore-bearing solutions were defined as $\mathrm{Na}$ Cl-type with range from 4.4 to $8.6 \mathrm{wt} \% \mathrm{NaCl}$ equivalent. The latest stage salinities ranged from 3 to $12 \mathrm{wt} \% \mathrm{NaCl}$ equivalent, where those from 10 to $12 \mathrm{wt} \%$ and from 6 to $8 \mathrm{wt} \% \mathrm{NaCl}$ equivalent, prevailed. This suggests that hydrothermal solutions within analysed quartz grains were at final mineralizing phase. Density of fluid inclusions ranged from 0.7 to $0.95 \mathrm{~g} / \mathrm{cm}^{3}$. Calculated pressures and paleo-depths of mineralisation ranged from 14 to 130 bar and from 0.6 to $0.8 \mathrm{~km}$.
\end{abstract}

Key words: lead-zinc, quartz, fluid inclusions, temperature, salinity, Zletovo mine.

\section{Izvleček}

Svinčevo cinkovo ( $\mathrm{Pb}-\mathrm{Zn}$ ) rudišče Zletovo $\mathrm{z}$ bogato sulfidno in porfirsko mineralizacijo leži v bližini vulkanskega centra Plavica (R. Makedonija). Analiza tekočinskih vključkov je pokazala, da so se homogenizacijske temperature gibale od 335 do $145^{\circ} \mathrm{C}$, kar odraža različne faze prisotnosti hidrotermalnih raztopin. Frekvence homogenizacijskih temperatur so se gibale od 265 do $125^{\circ} \mathrm{C}$, z najbolj prevladujočimi od 245 do $225^{\circ} \mathrm{C}$, od 225 do $205^{\circ} \mathrm{C}$ in od 145 do $125^{\circ} \mathrm{C}$. Z raziskavami smo potrdili, da so bile hidrotermalne rudonosne raztopine tipa $\mathrm{NaCl}$, in sicer $\mathrm{z}$ razponom od 4,4 do 8,6 ut.\% ekviv. NaCl. Slanost v zadnjih fazah prisotnosti raztopin je znašala od 3 do 12 ut.\% ekviv. NaCl. Podatki tako kažejo na to, da so bile hidrotermalne raztopine znotraj analiziranih kremenovih zrn v zadnji fazi mineralizacije. Gostota tekočinskih vključkov je znašala od 0,7 do $0,95 \mathrm{~g} / \mathrm{cm}^{3}$. Tlaki in paleo-globine pojava mineralizacije so znašali od 14 do 130 barov in od 0,6 do $0,8 \mathrm{~km}$.

Ključne besede: svinec-cink, kremen, tekočinski vključki, temperatura, slanost, rudnik Zletovo. 


\section{Introduction}

Research and exploitation of lead-zinc ore from Zletovo mine have recorded history of nearly a century, but detailed studies of ore fluids, as presented in this paper, are very rare. Namely, the Zletovo lead-zinc deposit has been the subject of exploitation since 1941. After the end of the Second World War, a modern mine with an annual production capacity of 400,000 t of ore was built at the Zletovo ore deposit. Thus, the Zletovo mine has been in continuous production for more than 75 years, with an average content of $8 \%$ of $\mathrm{Pb}+\mathrm{Zn}$ within the ore.

During the exploration of the Zletovo deposit, numerous detailed and special mineralogical and geochemical studies on evolution and lead-zinc mineralisation were performed. The most complex and complete published materials are as follows [1, 3, 4, 5-10].

The aim of this paper is to investigate the fluid inclusions in quartz samples taken from the ore parageneses in order to define the ore deposit origin through values of homogenisation temperature, salinity and pressures.

\section{Materials and methods}

\section{Geological setting and mineralisation}

The Zletovo lead-zinc deposit, located in the east of the Kratovo-Zletovo volcanogenic complex, occupies the central parts of the KratovoZletovo ore district or the south-eastern parts of the Zletovo ore field. The Zletovo lead-zinc deposit was formed by hydrothermal activity intimately associated with tertiary volcanism along the active continental margin. The major rock types in the area are andesite, dacite, dacitic ignimbrite and volcanic tuff $[1,3,11]$. Dacitic ignimbrite is the most common volcanic unit. The $\mathrm{Pb}-\mathrm{Zn}$ mineralisation at Zletovo is spatially and genetically related to fracture zones in the NW, NNW and ENE directions, which have served as the main conduits and depositional sites for hydrothermal fluids.

Ore bodies occur as veins, accompanied by impregnation and stockwork-disseminated ore mineralisation, most commonly in the selvage parts of the mineralized vein structures. The ore bodies are of variable dimensions in terms of strike, dip and size. Vein-type ore bodies have been determined to be $100-300 \mathrm{~m}$ in length (depending on the length of veins), and rarely over $5 \mathrm{~km}$ (the vein no. 10), whereas they have been traced as over $500 \mathrm{~m}$ in dip, and according to the data available so far, no change in continuity has been noticed with depth, which is very important fact for the deposit reserve potential. The ore veins are also variable, ranging from several centimetres to $2 \mathrm{~m}$ and rarely over $5 \mathrm{~m}$ in size. Thickening of veins occurred at places with great changes in their direction in both strike and dip. Investigations done so far have determined about 16 veins from NW-SE to NNW-SSE and ENE-WSW to E-W extension, most commonly subparallel to each other. Occasionally they bend and intersect (commonly under a sharp angle) such as ore veins 2, 3, 4, 6 and 7 (Figure 1). Termi-

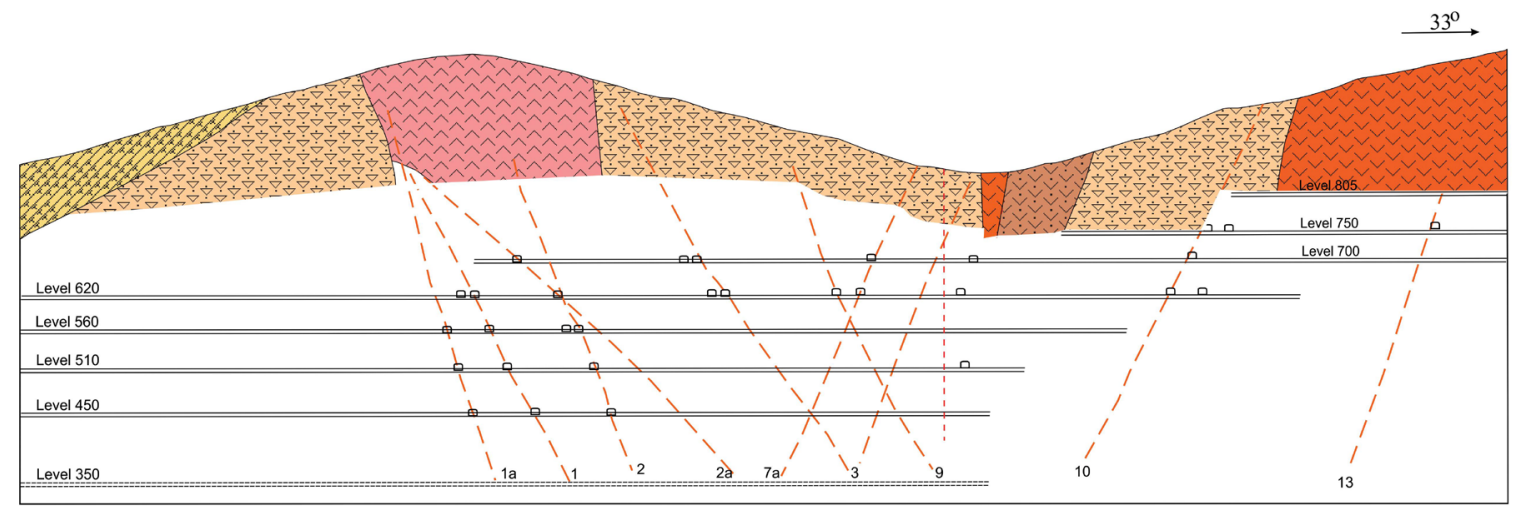

Andesite 20 Stratified tuffs

Figure 1: Geological cross section through the Zletovo Mine. 
nal branching of the main ore veins is common (ore vein 1) and results in the formation of apophyses of small dimensions.

The ore mineral association comprises galena as the principal ore mineral together with sphalerite and subordinate pyrite, siderite and chalcopyrite and rare pyrrhotite, marcasite and magnetite $[12,13]$. Veins typically contain large clasts or screens of altered dacitic and andesitic wall rocks. The altered clasts are weakly mineralized or barren.

\section{Analysis}

Fluid inclusion studies were conducted on doubly polished thin sections, made of six quartz samples (S1-S7, omitting S2) from the Zletovo mine, in which more than 130 separate fluid inclusions were investigated. Transparent, $150 \mu \mathrm{m}$ thick, polished plates were utilised, in which fluid inclusions (5-40 $\mu \mathrm{m}$ in size) in quartz were analysed. Fluid inclusions were almost evenly distributed in the studied quartz grains and only those with strong indications of primary origin [14], and thus interpreted as having been trapped during the mineralising event, were taken into account during the microthermometric studies; however, the possibility that some secondary inclusions have also been investigated cannot be excluded [15]. The study was performed using Nikon and Olympus BX51 optical microscopes, and at least 20 inclusions were found and defined in each analysed sampleQQ. Microthermometric data were obtained using a Linkam THMSG600 heating-freezing stage (with temperature range from -196 to $+600^{\circ} \mathrm{C}$ ) and TMS 90 controller attached to a conventional petrographic microscope. The stage was calibrated using the Synflinc set of synthetic fluid inclusions and revealed a precision of $\pm 0.1^{\circ} \mathrm{C}$ for the freezing runs and $\pm 5^{\circ} \mathrm{C}$ for temperatures near to or higher than $360^{\circ} \mathrm{C}$. Salinities were expressed as weight percent $\mathrm{NaCl}$ equivalent and were estimated from the melting temperatures of the last crystal of ice for two-phase fluid inclusions $[16,17]$. Eutectic temperatures were used to estimate the overall composition of the studied fluid inclusions by comparison with published data for different salt-water systems [15, 18]. The pressure of heterogeneous fluids was de-
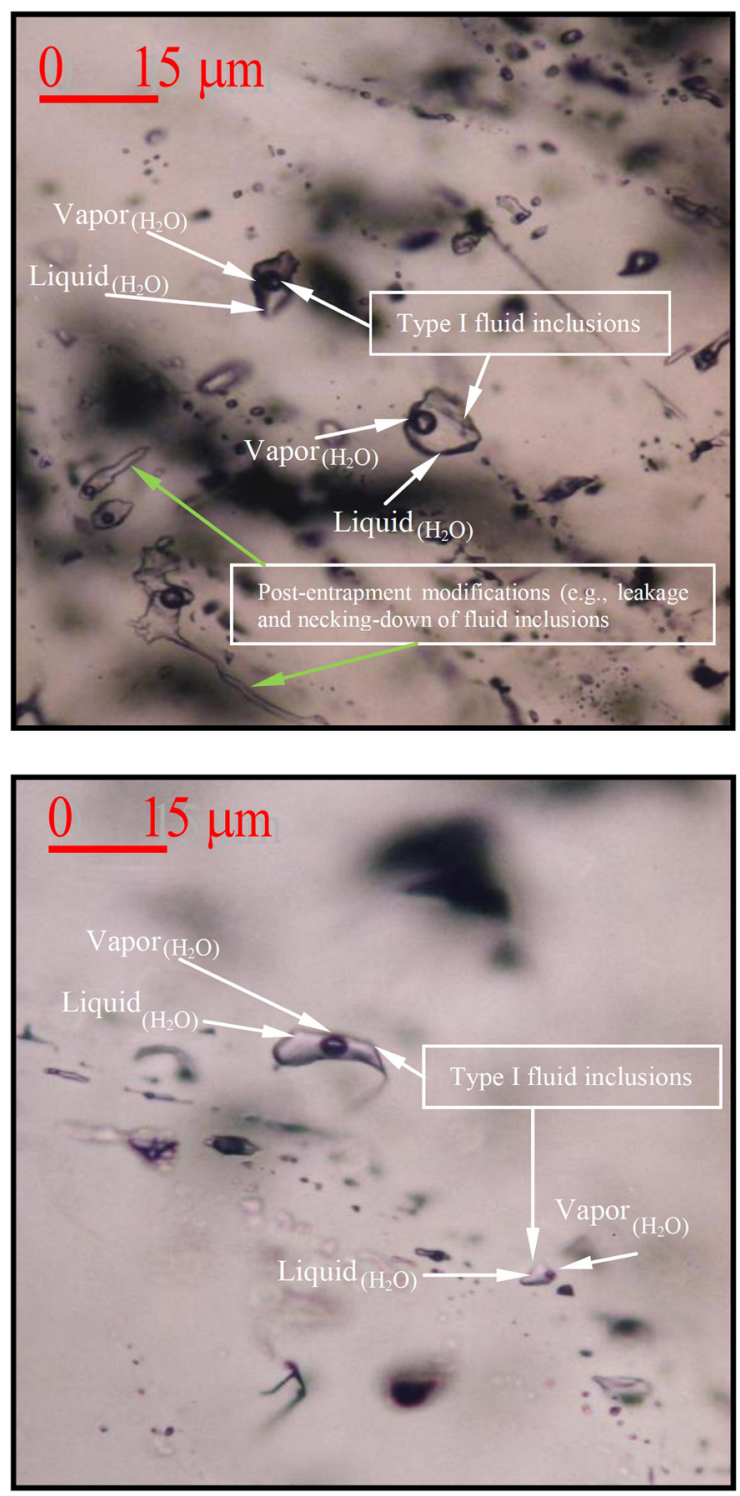

Figure 2: a) Large primary type I $(V+L)$ fluid inclusions; $b$ ) Large and minute primary type I $(V+L)$ fluid inclusions.

termined using the method of sections of isochors and isotherms [19].

As mentioned above, the fluid inclusions as remnants of ancient ore-bearing solutions from the Zletovo deposit were analysed by the analytical facilities of the Geological Department of Royal Holloway University in London, Egham, UK.

During the analysis, the following phenomena were analysed and interpreted: the homogenisation temperature $\left(T_{h}\right)$, the temperature of melting of the last ice crystal $\left(\mathrm{T}_{\mathrm{m}}\right)$, salinity ( $w \mathrm{t} \% \mathrm{NaCl}$ equivalent), density, pressure and determination of the primary or secondary ori- 
Table 1: Microthermometry data of studied fluid inclusions from the Zletovo deposit (R. Macedonia).

\begin{tabular}{ccccccc}
$\begin{array}{c}\text { Locality and } \\
\text { sample label }\end{array}$ & Mineral & $\begin{array}{c}\text { Fluid inclusion } \\
\text { type }\end{array}$ & \multicolumn{2}{c}{$\begin{array}{c}\text { Salinity (wt\% NaCl } \\
\text { equivalent) } \\
\text { Range }\end{array}$} & \multicolumn{2}{c}{$\begin{array}{c}\text { Homogenisation } \\
\text { temperature }\left({ }^{\circ} \mathbf{C}\right)\end{array}$} \\
Average & Range & Average \\
\hline Zletovo $(S-1)$ & Quartz & $\mathrm{P}$ & $3.1-11.8$ & 8.6 & $137.8-265.4$ & 196.2 \\
\hline Zletovo $(S-2)$ & Quartz & $\mathrm{P}$ & $1.7-5.4$ & 4.4 & $233-285$ & 251.2 \\
\hline Zletovo & Quartz & $\mathrm{P}$ & - & - & $304.0-368.0$ & 335.0 \\
\hline Zletovo & Quartz & Ps & - & - & $210.0-265.0$ & 235.0 \\
\hline Zletovo & Quartz & P & - & - & $109.0-163.0$ & 145.0
\end{tabular}

Note: P_Primary fluid inclusions; PS — Pseudosecondary fluid inclusions; samples S-1 and S-2 are from [11] and others are from [8].

gin of inclusion (Table 1). At least 20 inclusions were taken into account in each specimen, which should provide sufficient data to ensure the reliability of the parameters mentioned above. All the studied fluid inclusions were colourless. The analysed fluid inclusions were mainly of two phases type $(\mathrm{L}+\mathrm{V}$, where $\mathrm{L}$ is liquid and V is vapour; see Figures $2 \mathrm{a}$ and $2 \mathrm{~b}$ ), or liquid phase (L) and vapour phase (V), without the presence of $\mathrm{CO}_{2}$.

\section{Results and discussion}

Primary fluid inclusions in quartz vary in size from 3 to $7 \mu \mathrm{m}$ and locally up to $12-13 \mu \mathrm{m}$ (Figure 2). Some secondary liquid-rich inclusions occur along healed fractures that cut across different quartz grains and range from 1 to $5 \mu \mathrm{m}$ and typically have irregular shapes (Figure 2a, green arrows). The degree of fill of the fluid inclusions was calculated by the following equation:

$D_{f}=\frac{L}{L+V}$

where $D_{\mathrm{f}}$ stands for degree of fill of the inclusion, $L$ for liquid phase and $V$ for vapour phase. The degree of fill of the studied fluid inclusions was high, ranging from 0.70 to 0.95 . They consist of two phases $(L+V)$ with 5-30 vol.\% vapour. This gave us a basis for calculation of fluid inclusions densities later on. All the studied fluid inclusions were homogenized into a liquid phase. The salinity of solutions, in general, was low, ranging from 1.7 to $11.8 \mathrm{wt} \% \mathrm{NaCl}$ equivalent, with an average of 4.4-8.6 wt $\% \mathrm{NaCl}$ equivalent. In more than 120 individual fluid inclusions, in six quartz samples from Zletovo deposit, homogenisation temperatures $\left(\mathrm{T}_{\mathrm{h}}\right)$ were within the range of $109-368^{\circ} \mathrm{C}$. This range of homogenisation temperatures showed high consistency, bearing in mind the range of $150-350^{\circ} \mathrm{C}$ determined by former studies $[6,20]$. The $\mathrm{T}_{\mathrm{h}}$ range given above is characterised by two peak values of $130-180^{\circ} \mathrm{C}$ and $200-275^{\circ} \mathrm{C}$, which can be easily related to the polymetallic stage characterised by the assemblages of sphalerite-galena-pyrite-chalcopyrite and less abundant pyrite-galena-quartz. This is very similar to the data of [21] for the Maouduan deposit, where sulphides followed the sequence pyritesphalerite-chalcopyrite-galena. The capture temperatures of inclusions can be determined as medium to high. Here, it is necessary to point out that the homogenisation temperatures define the lowest temperature of mineralisation, while the temperatures determined by stable sulphur isotope geothermometers define the "real" temperatures of mineralisation [22-25]. For all of the studied fluid inclusions, temperatures of first ice melting $\left(\mathrm{T}_{\mathrm{m}}\right)$ within the range of -26 to $-20^{\circ} \mathrm{C}$ were determined, which suggests temperatures close to the eutectic temperature of the system $\mathrm{H}_{2} \mathrm{O}-\mathrm{NaCl}\left(-20.8^{\circ} \mathrm{C}\right)$, or the solution $\mathrm{NaCl}$ with $( \pm \mathrm{K})$, while $\mathrm{Ca}$ and $\mathrm{Mg}$ are absent since their eutectic temperature is significantly lower.

In accordance with data obtained from micro-thermometric analyses, diagrams show relations between parameters of the fluid in- 


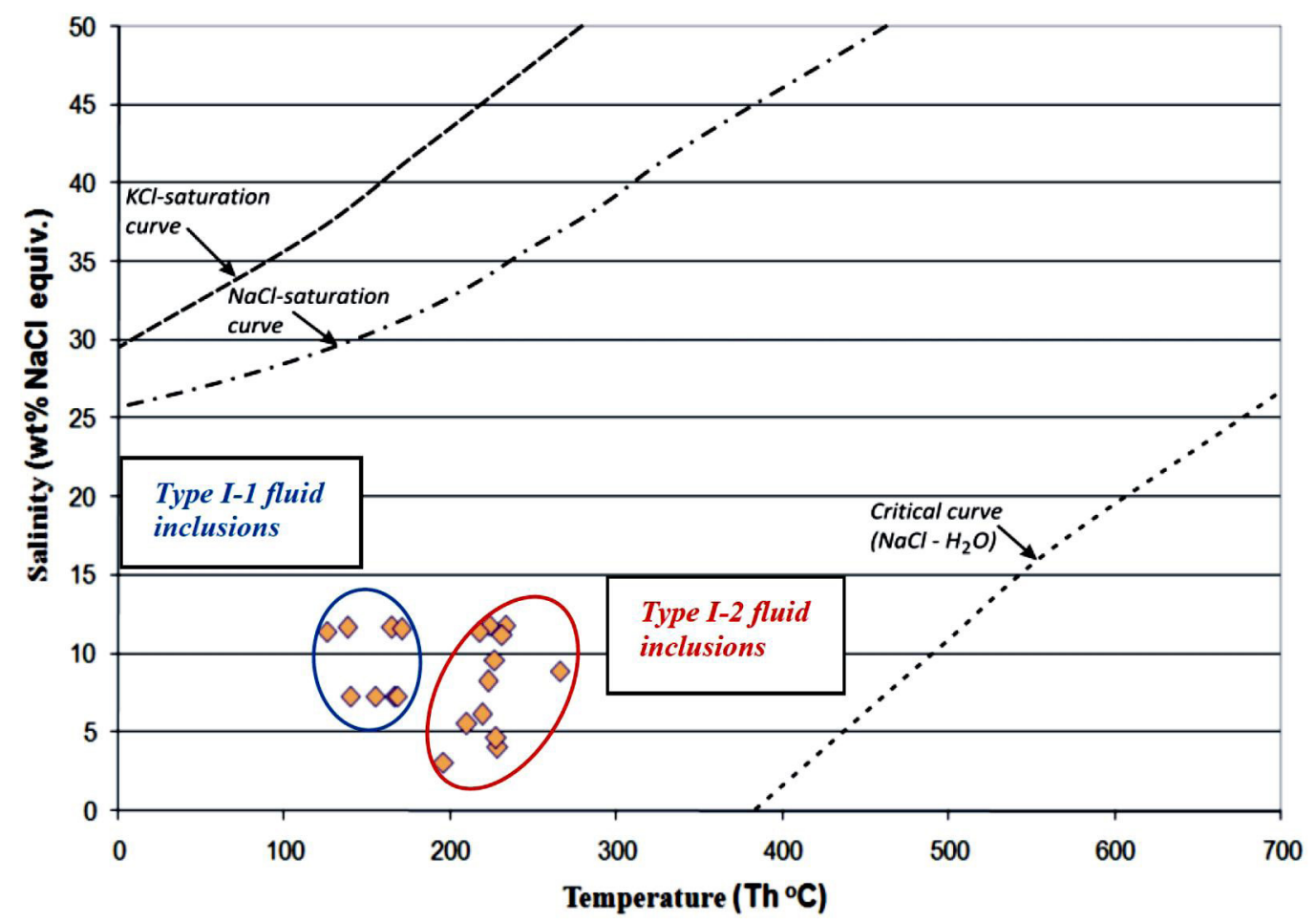

Figure 3: Relations of homogenization temperatures and salinities in fluid inclusions from Zletovo deposit.

clusions: salinity (wt $\% \mathrm{NaCl}$ equivalent) versus homogenisation temperature (Figure 3).

It points to a wide temperature range of fluid inclusions capture, indicating a long process of new material deliveries, which is supported by a salinity difference of up to $10 \mathrm{wt} \% \mathrm{NaCl}$ equivalent units. Such occurrences are very indicative of mineralisations with multiple pulsations and phase deposition of mineralisations. Fluid inclusion studies of ore-related minerals (in our case, quartz) constrain the fluid evolution in the later stages of development of the hydrothermal system. Homogenisation temperatures plotted against bulk salinity values clearly separate two types of fluid inclusions into two distinct groups, which strongly suggests the involvement of two distinct fluid types in the $\mathrm{Pb}-\mathrm{Zn}$ mineralisation event: a higher temperature $\left(>200^{\circ} \mathrm{C}\right)$, low-to-medium salinity (>7.5 wt $\% \mathrm{NaCl}$ equivalent) brine, represented by type I-2 fluid inclusions, and a lower temperature $\left(<200^{\circ} \mathrm{C}\right)$, low salinity $(<5.5 \mathrm{wt} \% \mathrm{NaCl}$ equivalent) type I-1 fluid inclusion (Figure 3 ). Post-entrapment modifications (e.g., leakage and necking-down; Figure 2a) could be invoked to explain the broad and contrasting range of homogenisation temperatures and salinities displayed by types I-1 and I-2 fluid inclusions. Data on the melting temperatures of the last ice crystal and homogenisation temperatures, as expected, have shown the very same grouping as in the Figure 3.

Also, that data shows that there is no direct relation between the melting temperature of the last ice crystal and the homogenisation temperature. Ice melting temperatures ranging from -5.5 to $-8.18^{\circ} \mathrm{C}$ yield salinities between 7.2 and $11.8 \mathrm{wt} \% \mathrm{NaCl}$ equivalent for type I-1 inclusions. In contrast, ice melting of type I-2 inclusions invariably takes place at temperature values ranging from -1.8 to $-8.3^{\circ} \mathrm{C}$, indicating a broader range of salinities (3.0-11.8 wt\% $\mathrm{NaCl}$ equivalent). Upon heating, total homogenisation of type I-1 fluid inclusions invariably occurred via the disappearance of vapour into the liquid phase between 130 and $180^{\circ} \mathrm{C}$. Fluid inclusions of type I-2, on the other hand, show vapour disappearance within the interval of $200-275^{\circ} \mathrm{C}$. Probably, type I- 2 is representative of mixing of less saline and colder (probably 

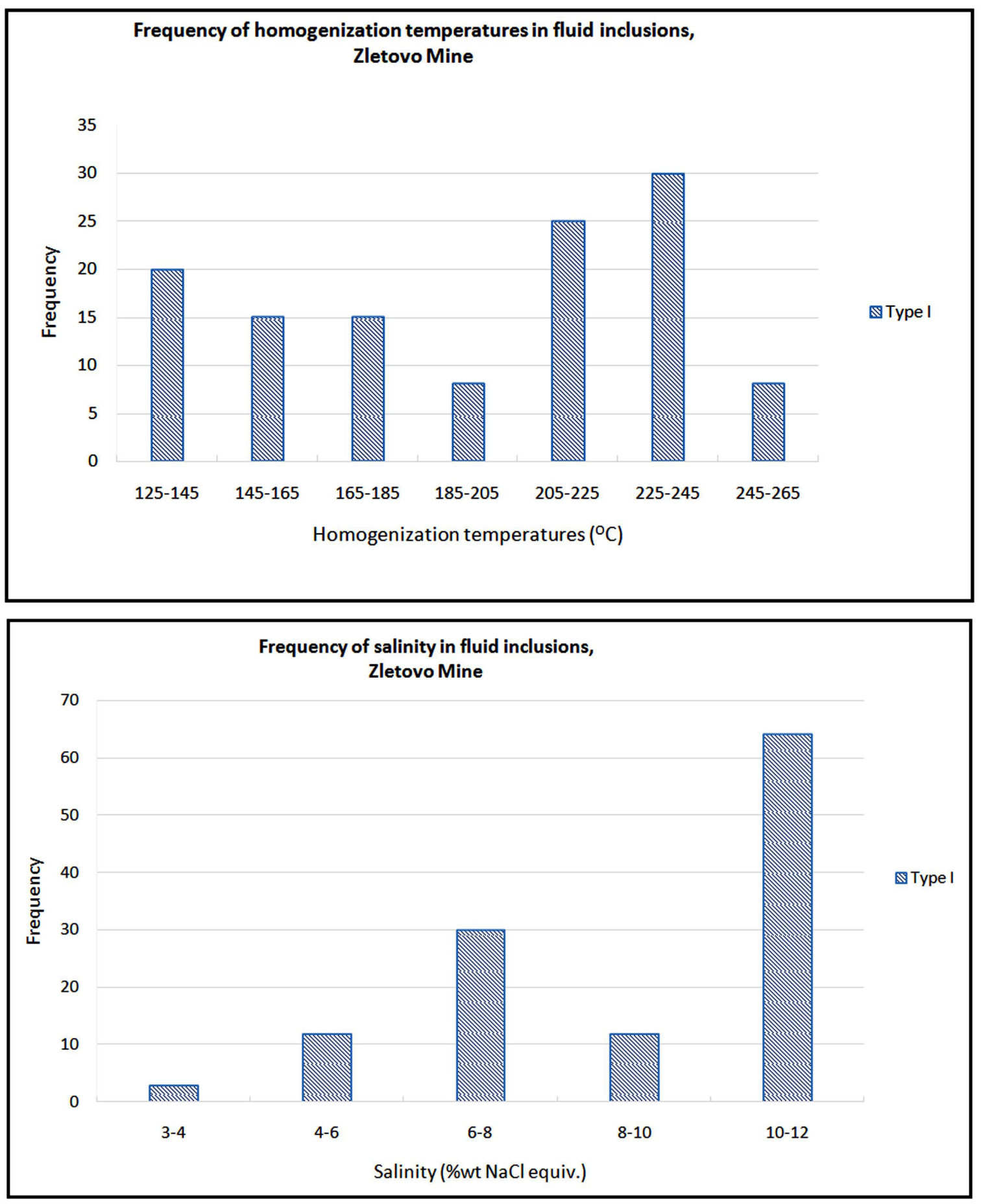

Figure 4: Relations of homogenization temperature vs. last ice crystal melting temperature in fluid inclu $\neg$ sions from the Zletovo deposit [9].

meteoric water) with magma water. Type I-1 shows a clear connection to I-2, that are inclusions with cooler fluid that survived the "leakage" and their $\mathrm{T}_{\mathrm{h}}$ increased significantly.
However, the most common were inclusions with homogenisation temperatures within the ranges of $225-245^{\circ} \mathrm{C}$ and $205-225^{\circ} \mathrm{C}$, while salinities showed the highest frequencies within the ranges of $10-12 \mathrm{wt} \%$ and $6-8 \mathrm{wt} \% \mathrm{NaCl}$ 
Table 2: Several the most crucial fluid inclusion parameters calculated from ours fluid inclusions study.

\begin{tabular}{ccccccc} 
& $\begin{array}{c}\mathbf{x} \\
(\mathbf{N a C l})\end{array}$ & $\begin{array}{c}\mathbf{w} \% \\
(\mathbf{N a C l})\end{array}$ & $\begin{array}{c}\text { Molar volume } \\
\left(\mathbf{c m}^{\mathbf{3}} \mathbf{/ m o l}\right)\end{array}$ & $\begin{array}{c}\text { Density } \\
\left(\mathbf{g} / \mathbf{c m}^{3}\right)\end{array}$ & $\begin{array}{c}\text { Temperature } \\
\text { homogenisation }\left({ }^{\circ} \mathbf{C}\right)\end{array}$ & $\begin{array}{c}\text { Pressure } \\
(\mathbf{M P a})\end{array}$ \\
\hline Sample 1 & 0.0282 & 8.6 & 20.490 & 0.93 & 198.2 & 1.41 \\
\hline Sample 3 & 0.0183 & 5.7 & 26.155 & 0.72 & 334.1 & 13.14 \\
\hline Sample 4 & 0.0220 & 6.8 & 21.779 & 0.87 & 244.5 & 3.48 \\
\hline Sample 5 & 0.0187 & 5.8 & 24.760 & 0.76 & 312.8 & 9.94 \\
\hline Sample 6 & 0.0155 & 4.9 & 21.099 & 0.88 & 217.9 & 2.16 \\
\hline Sample 7 & 0.0224 & 6.9 & 20.890 & 0.91 & 213.1 & 1.94 \\
\hline
\end{tabular}

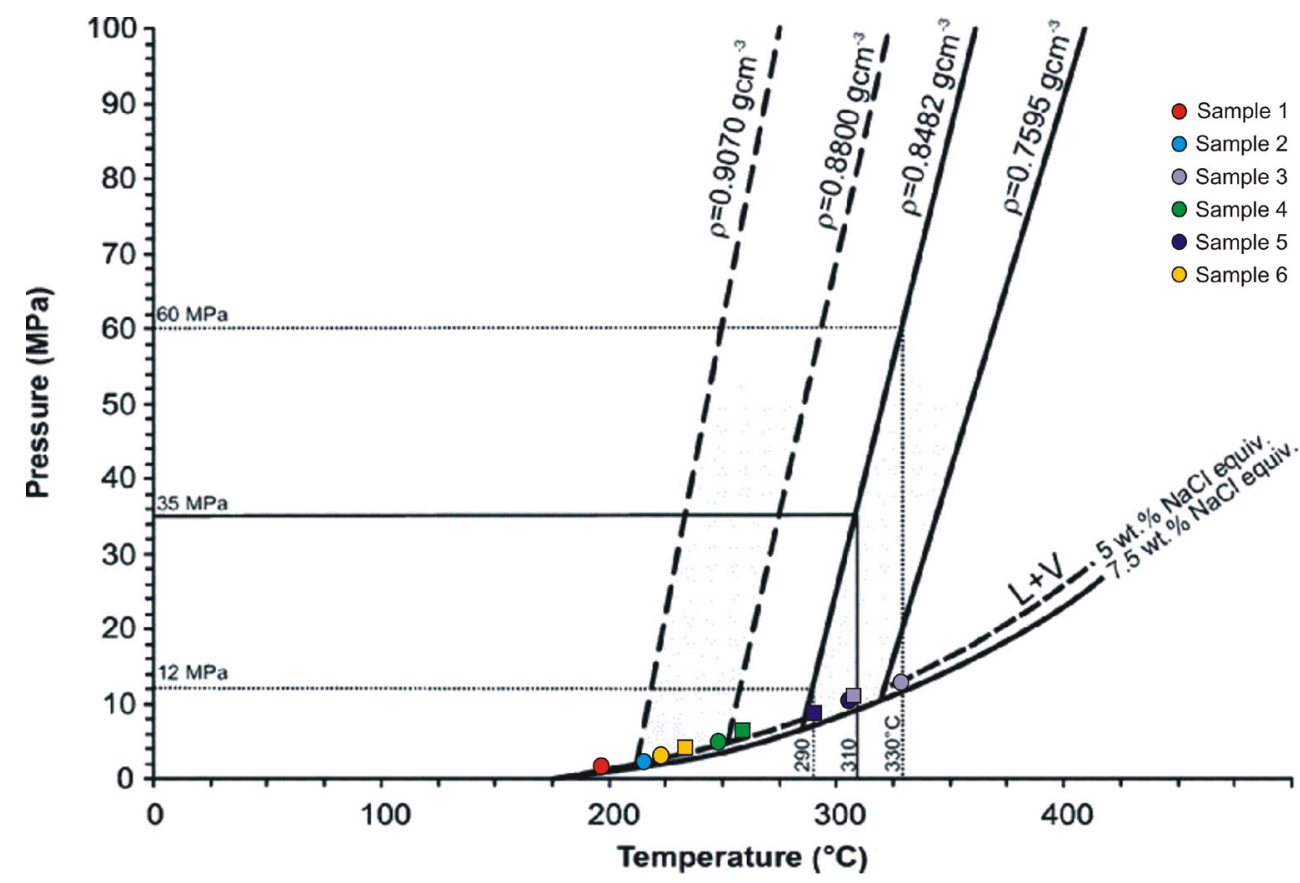

Figure 5: Histograms of a) homogenization temperatures and b) salinities of fluid inclusions in ore associated quartz samples from the Zletovo Mine.

equivalent (Figure 4). According to eutectic temperatures, solutions were probably of $\mathrm{Na}-\mathrm{Cl}^{ \pm} \mathrm{Cl}$ composition.

Calculations all fluid inclusions data from ours latest study, made in FLINCORE and AqCl following instructions [22], yielded the following parameters (Table 2).

Several findings emerged during the data processing from this study. Densities ranged from 0.72 to $0.93 \mathrm{~g} / \mathrm{cm}^{3}$. Here, we would like to remind that at high pressures the supercrit- ical fluid has a density similar to liquid water at the Earth's surface $\left(1 \mathrm{~g} / \mathrm{cm}^{3}\right)$, while at low pressures and high temperatures its density differs significantly from $1 \mathrm{~g} / \mathrm{cm}^{3}$. Low densities resulted in low solubility of ion materials, leading to relatively low mineralizing capacity of the ore-bearing solution [15]. Combining microthermometric data for the majority of fluid inclusions from the quartz $(4.9-8.6 \mathrm{wt} \% \mathrm{NaCl}$ equivalents, $T_{h}=198-334^{\circ} \mathrm{C}$ ) with P-T stability field limits maximum formation temperature 
at $334^{\circ} \mathrm{C}$ and total fluid pressure at $13.14 \mathrm{MPa}$. The data above (temperature of homogenisation, salinity, molar volume and density) gave us an opportunity to determine the pressures of formation of these particular parageneses (Figure 5, circles).

As it can be seen from the plot, the pressures ranged from 1.41 to $13.14 \mathrm{MPa}$. Based on this information, the palaeo-depths of mineralisation (during the capture of fluid inclusions [15]) ranged between 0.6 and $0.8 \mathrm{~km} \mathrm{[23],} \mathrm{which} \mathrm{is}$ largely consistent with the depths around $1 \mathrm{~km}$ in data given by [2] and indicates that the deposit was generated at subvolcanic levels and under strong influence of lithostatic and explosive pressures. Additionally, the spatial coexistence of types I-1 and I-2 fluid inclusions within the same assemblage also suggest that both fluids may have been present during the precipitation of the ore-related quartz within the timeframe of the $\mathrm{Pb}-\mathrm{Zn}$ mineralizing episode. Studied fluid inclusions in quartz samples taken from the ore veins no. 2, 3 and 12, Zletovo mine, were also followed by analysis of the sulphur isotopic compositions in galenite and sphalerite, as basic ore minerals in the paragenesis in which the treated quartz is located. The results of the isotopic analyses of sulphur in the main sulphide minerals were used for calculation of geothermometer temperatures and comparison with the values obtained from fluid inclusions in quartz. After that those values were used to obtain the pressures at which these parageneses had been deposited. Temperatures calculated from sulphur stable isotopes for sulphide-sulfide mineral pairs from the Zletovo deposit, followed directions given in representative literature [24-28]. Namely, our recent stable sulphur isotope data $\left(\mathrm{d}^{34} \mathrm{~S}\right.$; see Table 2) in samples from the Zletovo deposit have shown strong value compatibility with some of the previous researchers [29, 12]. In regards to sulphur stable isotopes geothermometers, we would like to stress out that a number of experimental studies have been performed to determine the temperature (in degrees Kelvin) dependence of equilibrium fractionation factors of sulphur isotopes between coexisting galena and sphalerite [30]. Through the years several equations occurred in literature. Some of the most common examples were those given below:

Some of the earliest equations addressing sulphur stable isotopes thermometers [31], it was found that:

$\Delta_{Z n S-P b S}=\left(0.63 / T^{2}\right) \cdot 10^{6}$.

Certain researchers [32] later have proposed the equation:

$\Delta_{Z n S-P b S}=\left(0.80 / T^{2}\right) \cdot 10^{6}$.

While particular variation of the equation was suggested some other authors too [33]:

$\Delta_{Z n S-P b S}=\left(0.70 / T^{2}\right) \cdot 10^{6}$.

Detailed study of equations above has shown good agreement between values calculated from Equation (3) and filling temperatures of fluid inclusions from several ore deposits [34]. One of the most preferred equations was the one given below [24]:

$\Delta_{Z n S-P b S}=\left(0.73 / T^{2}\right) \cdot 10^{6}$.

Authors of this paper, based on numerous references, have decided to use Equation (4) to calculate temperatures (Table 3). We have used sphalerite-galena (in paragenesis with quartz from which originated measured fluid inclusions), as the most commonly used pair that in many cases yields temperatures consistent with those obtained from fluid inclusion data, which suggests that sphalerite and galena in numerous deposits are precipitated by similar mechanisms and under similar conditions [35] while eventual inconsistent temperatures obtained from this geothermometer in some studies elsewhere has been attributed to isotopic disequilibrium $[36,30]$.

The isotopic sphalerite-galena geothermometer yielded temperatures ranging from 154 to $309^{\circ} \mathrm{C}$ according to Equation (4) already mentioned above. Temperatures for the Zletovo deposit estimated with the sulphur isotope sphalerite-galena geothermometer are plotted versus fluid inclusion homogenisation temperatures in Figure 6. 
Table 3: Analytical data for coexisting sphalerite and galena crystallized during simultaneous mineralisation within the same ore vein, distribution, sulphur isotope fractionation and estimated mineralisation temperatures.

\begin{tabular}{|c|c|c|c|c|c|c|c|c|c|c|c|}
\hline No. & $\begin{array}{c}\text { Sample } \\
\text { No. }\end{array}$ & & Mineral & $\begin{array}{c}\text { No. of } \\
\text { vein or } \\
\text { horizon }\end{array}$ & ${ }^{34} S /{ }^{32} S$ & $\delta^{34} S \%$ & $\delta \mathrm{A}-\boldsymbol{\delta} \mathrm{B}$ & Pair & $1000 \ln \alpha$ & $\begin{array}{c}\mathrm{T} \\
\text { (Kelvin) }\end{array}$ & $\mathrm{T}\left({ }^{\circ} \mathrm{C}\right)$ \\
\hline 1 & $69 z$ & $\delta \mathrm{A}$ & Sphalerite & $\begin{array}{c}\text { vein } \\
3, h-625\end{array}$ & 22.231110 & 0.5 & -2.3 & $69 z-70 z A$ & -2.29621226 & 563.8394 & 290.6894 \\
\hline 2 & $70 \mathrm{zA}$ & $\delta \mathrm{B}$ & Galena & $\begin{array}{c}\text { vein } \\
3, h-625\end{array}$ & 22.282216 & 2.8 & & & & & \\
\hline 3 & $12 \mathrm{z}$ & $\delta \mathrm{A}$ & Sphalerite & $\begin{array}{c}\text { vein } \\
2, \mathrm{~h}-510\end{array}$ & 22.224444 & 0.2 & 2.9 & $12 z s-12 z g$ & 2.903631577 & 501.4073 & 228.2573 \\
\hline 4 & $12 z$ & $\delta \mathrm{B}$ & Galena & $\begin{array}{c}\text { vein } \\
2, \mathrm{~h}-510\end{array}$ & 22.160006 & -2.7 & & & & & \\
\hline 5 & M 71 & $\delta \mathrm{A}$ & Sphalerite & $\begin{array}{c}\text { vein } \\
12, \mathrm{~h}-490\end{array}$ & 22.155562 & -2.9 & -4 & M71s-M71g & -4.003608591 & 427.0076 & 153.8576 \\
\hline 6 & M 71 & $\delta \mathrm{B}$ & Galena & $\begin{array}{c}\text { vein } \\
12, \mathrm{~h}-490\end{array}$ & 22.244442 & 1.1 & -2.5 & M71s-M76g & -2.504133126 & 539.9241 & 266.7741 \\
\hline 7 & M 76 & $\delta \mathrm{B}$ & Galena & $\begin{array}{c}\text { vein } \\
12, \mathrm{~h}-490\end{array}$ & 22.211112 & -0.4 & & & & & \\
\hline 8 & M 39 & $\delta \mathrm{A}$ & Sphalerite & $\begin{array}{c}\text { vein } \\
3, \mathrm{~h}-700\end{array}$ & 22.225545 & 0.3 & 2 & M39s-M39g & 2.156966909 & 581.7544 & 308.6044 \\
\hline 9 & M 39 & $\delta \mathrm{B}$ & Galena & $\begin{array}{c}\text { vein } \\
3, \mathrm{~h}-700\end{array}$ & 22.177657 & -1.7 & & & & & \\
\hline
\end{tabular}

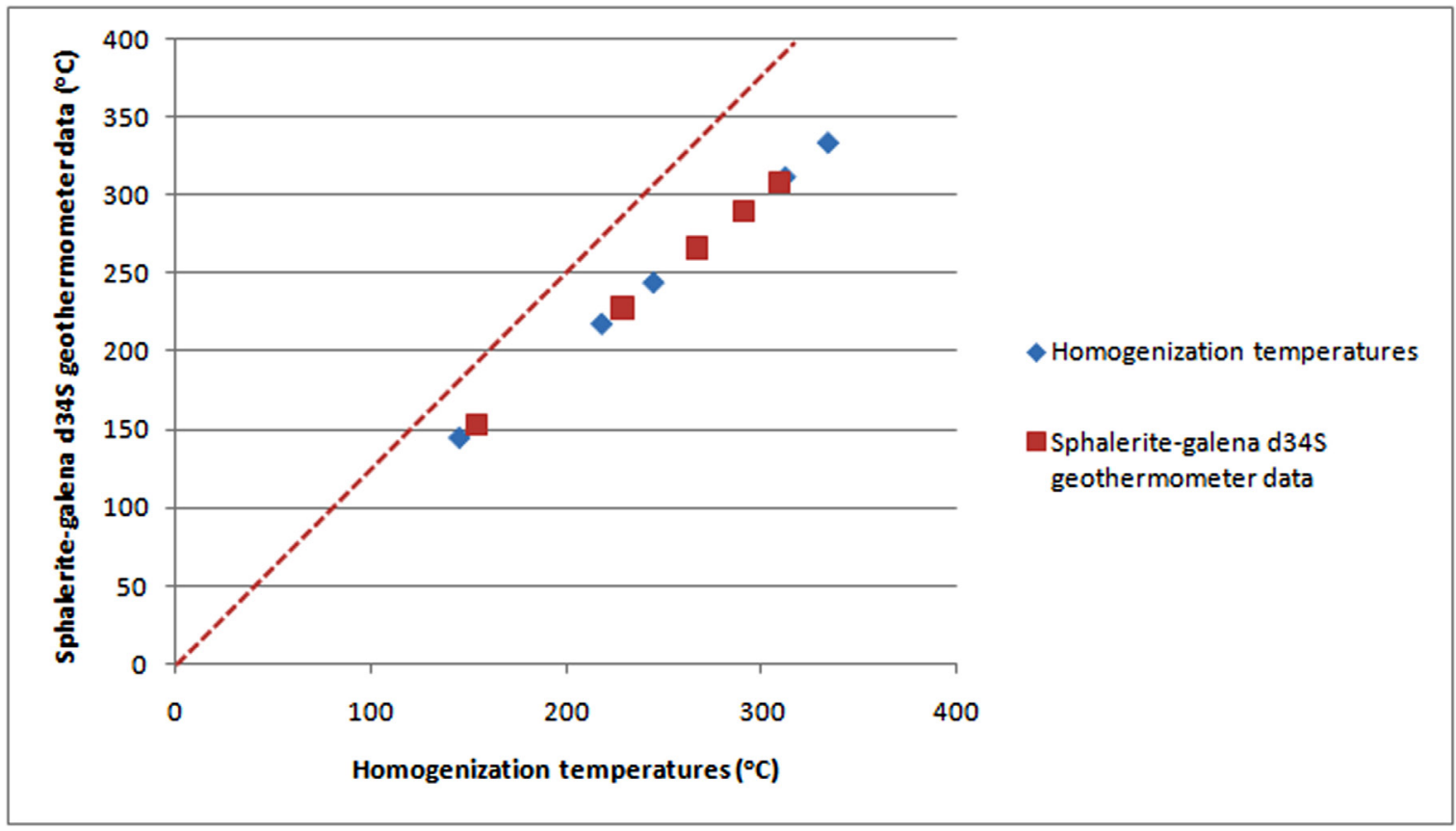

Figure 6: Changes in density and gas pressure of the liquid water [24, 9]. 


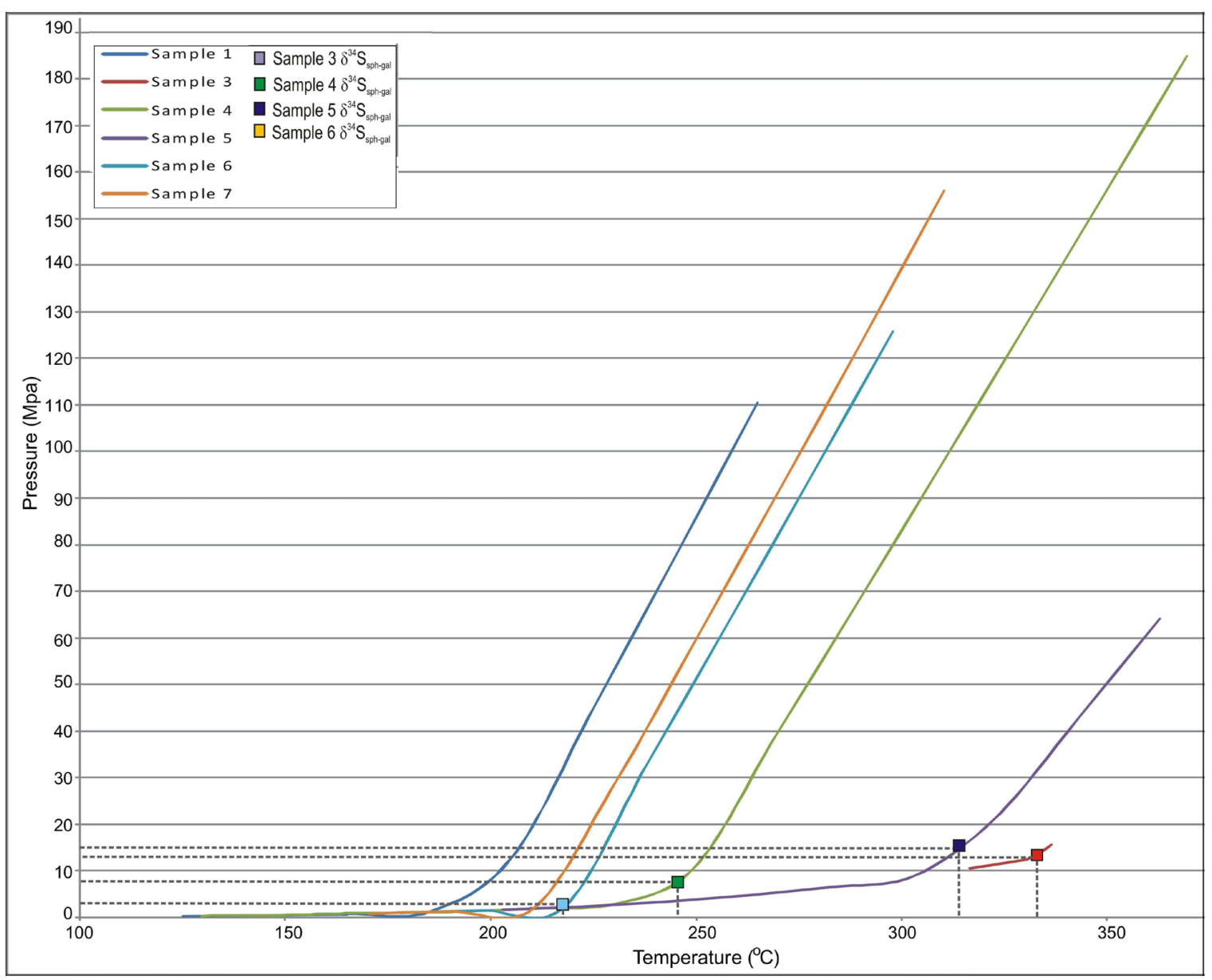

Figure 7: Density changes of supercritical fluid as a function of pressure and temperature (basic plot data [25] and [9]).

The majority of sulphur isotope mineral pair (sphalerite-galena) data yield isotopic temperatures $\left(154-309^{\circ} \mathrm{C} \pm 6^{\circ} \mathrm{C}\right)$ in general agreement with fluid inclusions data. This suggests that isotopic equilibrium was established between the sphalerite and galena and was not affected by an eventual re-equilibration. Thus, the sphalerite-galena geothermometer, along with fluid inclusion results, appears to give correct temperatures for ore formation. Here, we would like to stress out that Equation (4) yielded values are in good agreement with homogenisation temperatures (Figure 6).

Using solely the data from our research (fluid inclusions and sulphur stable isotopes), as well as their compilation in Excel, an isochore diagram was constructed (Figure 7).

From the plot above (Figure 7), we obtained confirmation of the data obtained from the similar diagram above (Figure 5). As it can be seen, these pressures only slightly or not at all differ from the pressures determined solely based on fluid inclusions data, which point out to an equilibrium of the system at the moment of paragenesis deposition.

\section{Conclusions}

The main ore parageneses in the Zletovo mine are galena-sphalerite ones, usually followed by quartz, pyrite and chalcopyrite, which determines the hydrothermal nature of this famous vein type of lead-zinc deposit. The selected quartz grains, where fluid inclusions have been identified and measured originates from the main ore parageneses with galena and sphalerite prevailing, followed by pyrite, chal- 
copyrite, calcite, kaolinite and others. Homogenisation temperatures were within the range of $335-145^{\circ} \mathrm{C}$ and reflect phases of pulsation of hydrothermal solutions that have been classified into four separate and consecutive groups from the highest temperature down to the lowest. Also, it was confirmed that the hydrothermal ore-bearing solution was of NaCl-type with salinity ranging from 4.4 to $8.6 \mathrm{wt} \% \mathrm{NaCl}$ equivalent. Density or fulfilment of fluid inclusions with liquid phase was within the range of $0.7-0.95 \mathrm{~g} / \mathrm{cm}^{3}$. Calculated pressures and paleo-depths of mineralisation were probably within the range of $1.41-313.14 \mathrm{MPa}$ and $0.6-0.8 \mathrm{~km}$, respectively. The latest data obtained with the study of fluid inclusions within the quartz from ore veins from the Zletovo mine are quite similar to some older data [6], with certain differences in the concentration of $\mathrm{NaCl}$ $(10-25 \mathrm{wt} \% \mathrm{NaCl}$ equivalent), which is probably due to analysis of fluid inclusions from cleophane varieties of sphalerite and barites in former studies. Calculation of the homogenisation temperature frequencies and salinities clearly points to the productive solutions from which the primary parageneses were deposited.

\section{References}

[1] Serafimovski, T. (1990): Metallogeny of the Lece-Chalkidiki zone. Ph.D. Thesis. Faculty of Mining and Geology-Stip: University "Sts. Cyril and Methodius"-Skopje; $390 \mathrm{p}$.

[2] Serafimovski, T., Janković, S., Čifliganec, V. (1995): Alpine Metallogeny and Plate Tectonics in the SW Flank of the Carpatho-Balkanides. Geologica Macedonica, 9(1), pp. 3-14.

[3] Serafimovski, T., Aleksandrov, M. (1995): Lead-zinc deposits and occurrences in the Republic of Macedonia. Faculty of Mining annd Geology-Stip, University "Sts. Cyril and Methodius"-Skopje, Special Issue No. 4, 387 p. [in Macedonian with extended English summary].

[4] Janković, S. (1997): The Carpatho-Balkanides and adjacent area: a sector of the Tethyan Eurasian metallogenetic belt. Mineralium Deposita, 32(5), pp. 426-433.

[5] Petković, M. (1982): Regional and detailed metallogenetic explorations of the Zletovo ore field. Faculty of Mining and Geology-Belgrade, 78 p. [in Serbian].
[6] Blečić, N. (1983): Sources of ore components in hydrothermal deposits (comparative analysis of genetic models on the example of the Zletovo mine deposit). Ph.D. Thesis: Faculty of Mining and Geology, Belgrade, 247 p. [in Serbian].

[7] Serafimovski, T. (1993): Structural-metallogenetic features of the Lece-Chalkidiki zone: Types of deposits and zonation. Faculty of Mining and Geology-Stip, Special issue No. 2, 235 p. [in Macedonian].

[8] Efremov, I. (1993): Metalogenija na Kratovsko-Zletovskata vulkanska oblast. Ph.D. Thesis. Rudarsko-geološki fakultet: Štip; 286 p.

[9] Serafimovski, T., Lazarov, P., Tasev, G. (2005): Sulfosalt mineral compositions from the № 10 vein, Zletovo lead-zinc deposit, Macedonia. Mineral Deposit Research: Meeting the Global Challenge, Ed.Jingwen Mao and Frank P. Bierlein. $8^{\text {th }}$ SGA Biennial Meeting, Beijing, China, pp. 461-464.

[10] Serafimovski, T., Dolenec, T., Tasev, G. (2006): New data concerning the major ore minerals and sulphosalts from the $\mathrm{Pb}-\mathrm{Zn}$ Zletovo Mine, Macedonia. RMZ-materials and geoenvironment, 52(3), pp. 535-548.

[11] Tasev, G. (2003): Polymetallic mineralizations related to the Tertiarymagmatism in the Republic of Macedonia. Master thesis. Stip: Faculty of Mining and Geology; $176 \mathrm{p}$.

[12] Mudrinić, C., Serafimovski, T. (1990-91): Geochemical and geochronological examinations by isotopes in Zletovo ore field. Geologica Macedonica, 5(1), pp. 105-120.

[13] Serafimovski, T., Tasev, G. (2003): The Zletovo Subvolcanic Hydrothermal Pb-Zn Mineral Deposit in the Republic of Macedonia. Geodynamicsand Ore Deposit Evolution of the Alpine-Balkan-Carpathian-Dinaride Province. Final GEODE-ABCD Workshop. Programme and Abstracts. Seggauberg, Austria, 22-24 March, 2003, pp. 50-51.

[14] Goldstein, R.H., Reynolds, T.J. (1994): Systematics of fluid inclusions in diagenetic minerals, SEPM Short Course 31. Society for Sedimentary Geology, 199 p.

[15] oedder, E. (1984): Fluid inclusions. Reviews in mineralogy, 12, Mineralogical Society of America, 644 p.

[16] Bodnar, R.J. (1993): Revised equation and table for determining the freezing point depression of $\mathrm{H}_{2} \mathrm{O}-\mathrm{Na}$ $\mathrm{Cl}$ solutions. Geochimica et Cosmochimica Acta, 57, pp. 683-684.

[17] Sterner, S.M., Hall, D.L., Bodnar, R.J. (1988): Synthetic fluid inclusions. V. Solubility relations in the system $\mathrm{NaCl}-\mathrm{KCl}-\mathrm{H}_{2} \mathrm{O}$ under vapor saturated conditions. Geochimica et Cosmochimica Acta, 52, pp. 989-1005. 
[18] Vanko, D.A., Bodnar, R.J., Sterner, S.M. (1988): Synthetic fluid inclusions. VIII. Vapor-saturated halite solubility in part of the system $\mathrm{NaCl}-\mathrm{CaCl}_{2}-\mathrm{H}_{2} \mathrm{O}$, with application to fluid inclusions from oceanic hydrothermal systems. Geochimica et Cosmochimica Acta, 52, pp. 2451-2456.

[19] Thiery, R., Kerkhof, A.M., Dubessy, J. (1994): VX properties of $\mathrm{CH}_{4}-\mathrm{CO}_{2}$ and $\mathrm{CO}_{2}-\mathrm{N}_{2}$ fluid inclusions: modeling for $\mathrm{T}<31^{\circ} \mathrm{C}$ and $\mathrm{P}<400$ bars. European Journal of Mineralogy, 6, pp. 753-771.

[20] Tasev, G., Serafimovski, T. (2012): Fluid inclusions study in the quartz from the Zletovo Mine. Macedonian Geological Society, Second Congress of Geologists of the Republic of Macedonia, Proceedings book (eds. Jovanovski, M., Boev, B.), Special Issue of Geologica Macedonica, 3, pp. 83-90.

[21] Li, Y.J., Wei, J.H., Chen, H.Y., Tan, J., Fu, L.B., Wu, G. (2011): Origin of the Maoduan Pb-Zn-Mo deposit, eastern Cathaysia Block, China: geological, geochronological, geochemical, and $\mathrm{Sr}-\mathrm{Nd}-\mathrm{Pb}-\mathrm{S}$ isotopic constraints. Mineralium Deposita, 47(7).

[22] Bakker, R.J. (2003): Package FLUIDS 1. Computer programs for analysis of fluid inclusion data and for modelling bulk fluid properties. Chemical Geology, 194, pp. 3-23.

[23] Prokof'ev, V.Y., Pek, A.A. (2015): Problems in Estimation of the Formation Depth of Hydrothermal Deposits by Data on Pressure of Mineralizing Fluids. Geology of Ore Deposits, 2015, 57(1), pp. 1-20.

[24] Ohmoto, H., Rye, R.O. (1979): Isotopes of sulphur and carbon. In: Geochemistry of Hydrothermal Ore Deposits, $2^{\text {nd }}$ edn., Barnes, H.L. (ed.). John Wiley and Sons: New York; pp. 509-567.

[25] Ohmoto, H. (1986): Stable istope geochemistry of ore deposits. In: Stable istope in high temperature geological processes, Valley, J.W., Taylor, H.P. Ir., O’Neil, J.R (eds.). Reviews in Mineralogy and Geochemistry, 16, pp. 491-559.

[26] Rye, R., Hall, W., Ohmoto, H. (1974): Carbon, Hydrogen, Oxygen and Sulphur isotope Study of the LeadSilver-Zinc Deposit, Southern California. Economic Geology, 69, pp. 468-481.

[27] Shelton, K.L., Rye, D.M. (1982): Sulfur isotopic compositions of ores from Mines Gaspe', Quebec: an example of sulfate-sulfide isotopic disequilibra in ore-forming fluids with applications to other porphyry-type deposits. Economic Geology, 77, pp. 1688-1709.

[28] Brownlow, H.A. (1996): Geochemistry. $2^{\text {nd }}$ Edition. U.S.A: Prentice Hall, Inc., 580 p.

[29] Drovenik, M., Leskovsek, H., Pezdic, I., Strucl, I., (1970). Isotopic composition of sulfur in sulfides from some Yugoslavian deposits (Izotopska sestava zvepla v sufidih nekaterih jugoslovenskih rudisc). Materials and Geoenvironment (former Mining and Metallurgy Quaterly), 17: 153-173 [in Slovenian].

[30] Bortnikov, N.S., Dobrovol'skaya, M.G., Genkin, A.D., Naumov, V.B., Shapenko, V.V. (1995): Sphalerite-Galena Geothermometers: Distribution of Cadmium, Manganese and the Fractionation of Sulfur Isotopes. Economic Geology, 90, pp. 155-180.

[31] Grootenboer, J., Schwarcz, H.P. (1969): Experimentally determined sulfur isotope fractionations between sulfide minerals. Earth and Planetary Science Letters, 7, pp. 162-166.

[32] Kajiwara, J., Krouse, H.R. (1971): Sulfur isotopic partitioning in metallic sulfides systems. Canadian Journal of Earth Sciences, 8, pp. 1397-1422.

[33] Czamanske, G.K., Rye, R.O. (1974): Experimentally determined sulfur isotope fractionations between sphalerite and galena in the temperature range $650^{\circ} \mathrm{C}$ to $275^{\circ}$ C. Economic Geology, 69, pp. 17-25.

[34] Rye, R.O. (1974): A comparison of sphalerite-galena sulfur isotope temperatures with filling temperatures of fluid inclusions. Economic Geology, 69, pp. 26-32.

[35] Misra, C.K. (2000): Understanding Mineral Deposits. Kluwer Academic Publishers, Dodrecht, Netherland, $845 \mathrm{p}$.

[36] Yamamoto, M., Endo, M., Ujihira, K. (1984): Distribution of selenium between galena and sphalerite. Chemical Geology, 42, pp. 243-248. 